\title{
Anisotropy Effect of Masonry on the Behaviour and Bearing Capacity of Masonry Walls
}

\author{
M. Smilovićc Zulim (D) and J. Radnić \\ University of Split, Faculty of Civil Engineering, Architecture and Geodesy, 21000 Split, Croatia \\ Correspondence should be addressed to M. Smilović Zulim; marija.smilovic@gradst.hr
}

Received 10 October 2019; Revised 9 January 2020; Accepted 20 January 2020; Published 19 February 2020

Academic Editor: Hamed Akhavan

Copyright (c) 2020 M. Smilović Zulim and J. Radnić. This is an open access article distributed under the Creative Commons Attribution License, which permits unrestricted use, distribution, and reproduction in any medium, provided the original work is properly cited.

\begin{abstract}
Firstly, an updated numerical model for the numerical analysis of planar unreinforced and confined masonry walls is presented. The model can simulate the main nonlinear material effects of masonry and reinforced concrete. A simplified anisotropic constitutive model for masonry is developed and presented. The criteria for the limit bearing capacity and collapse of masonry are separately defined for normal stresses only and for normal and shear stresses. The presented numerical model is verified and used to analyse the anisotropy effect of masonry on the behaviour of unreinforced and confined two-story anisotropic masonry walls with different coefficients of anisotropy, wall lengths, and quality of masonry under horizontal static forces. The influence of the anisotropy coefficient of the masonry on the response of the walls is discussed in detail, and the main conclusions are given.
\end{abstract}

\section{Introduction}

Unreinforced and confined masonry walls are complex structures that are primarily composed of masonry and concrete elements, such as foundations, tie columns, and tie beams. The masonry is formed by masonry units, which are connected by binder material in horizontal and vertical joints. Due to the different properties of vertical and horizontal joints, and especially because the properties of masonry units often differ in the vertical and horizontal directions, the masonry is always anisotropic. If the plaster is included in the bearing capacity of masonry, especially if it is reinforced, the structure of masonry walls becomes even more complicated. Uplifting and slippage of the foundation from the ground often occur under the action of horizontal forces on the walls, which also complicates reliable analysis of these complex structures. The main subject of this paper is a numerical simulation of the anisotropy effect of masonry on the behaviour and bearing capacity of unreinforced and confined masonry walls.

Numerous numerical models for the simulation of the anisotropic properties of masonry have been developed. One of the first nonlinear models for masonry was proposed by
Page [1-3], which considered the masonry to be a two-phase material composed of bricks and mortar. Dhanasekar et al. [4] defined a failure surface of masonry as composed of three elliptical cones. Andreaus [5] carried out a relatively comprehensive study, taking into account different failure modes of masonry using three failure criteria, namely, modified Mohr-Coulomb friction law, maximum tensile strain criterion, and maximum compressive stress criterion. Lourenco et al. [6-8] defined a limiting surface to describe the orthotropic behaviour of masonry with a material admissible field bounded by a Hill-type yield criterion for compression and a Rankine-type yield criterion for tension. Syrmakezis and Asteris [9] used a third-order polynomial to mathematically describe the failure surface. Berto et al. [10] developed an orthotropic damage model based on the definition of four independent internal damage parameters, two parameters in compression and two parameters in tension. Calderini et al. [11] described the anisotropic damage process and the dissipative behaviour of masonry structures under static incremental and dynamic loads. Pela et al. $[12,13]$ presented a plane-stress damage macromodel for orthotropic masonry based on the concept of mapped tensors from the orthotropic real space. Lishak et al. [14] 


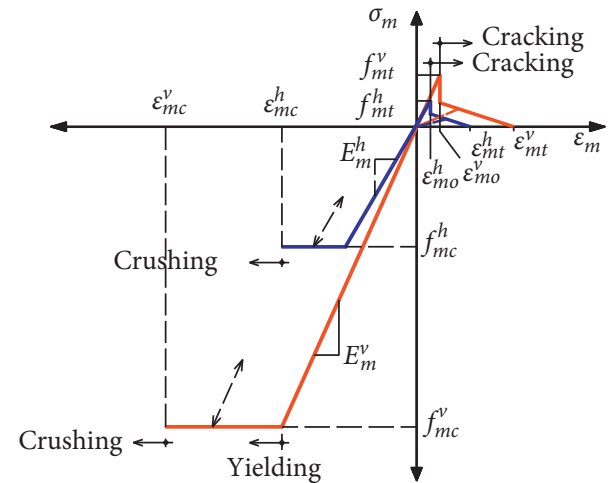

- Vertical direction

— Horizontal direction

(a)

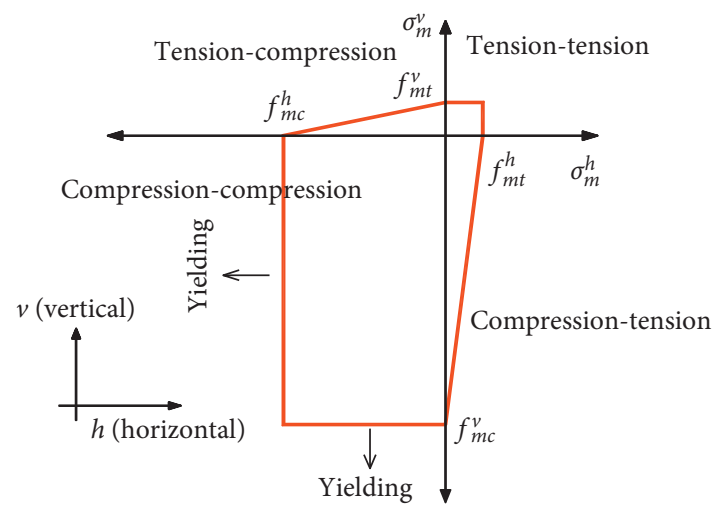

(b)

Figure 1: Adopted orthotropic masonry model under normal stresses: (a) 1D representation; (b) 2D representation.

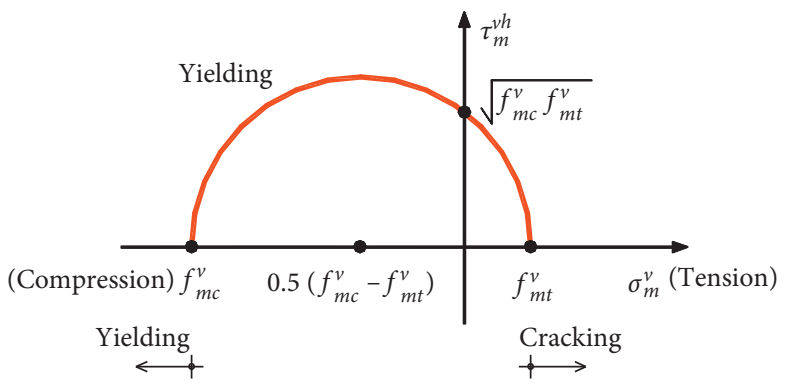

- Vertical direction

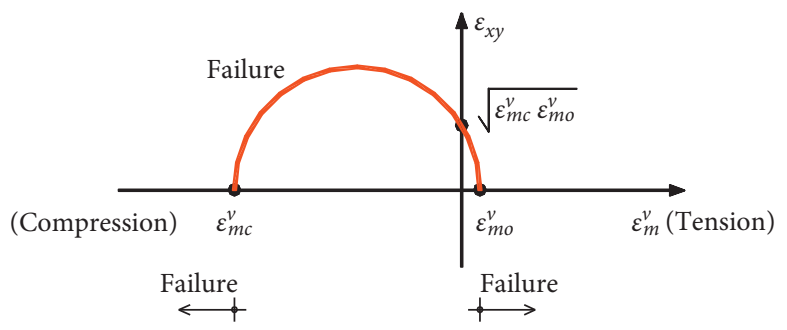

- Vertical direction

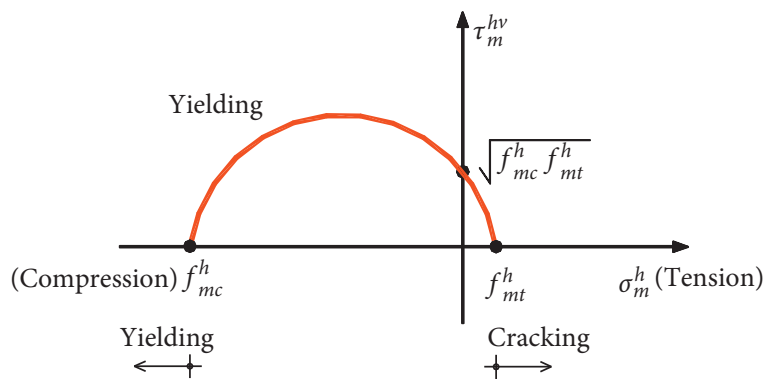

- Horizontal direction

(a)

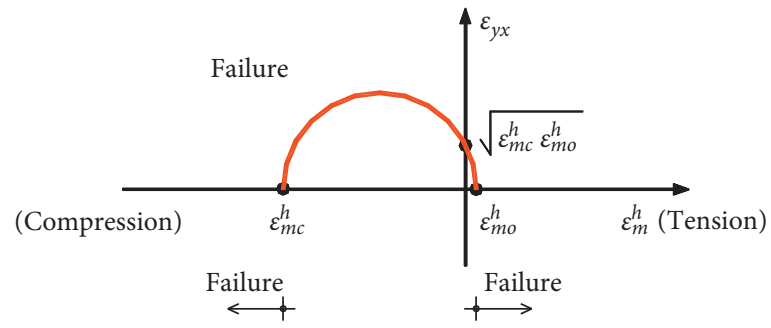

- Horizontal direction

(b)

FIgURE 2: Adopted orthotropic masonry model under normal and shear stresses: (a) the yielding of the masonry; (b) the failure of the masonry.

developed phenomenological masonry failure criteria for use in numerical calculations based on models where the masonry is considered an orthotropic homogeneous material. Ghiassi et al. [15] presented an orthotropic macromodel for nonlinear static analysis of masonry walls. Grande et al. [16] presented a frame element model for evaluating the nonlinear response of unstrengthened and FRPstrengthened masonry panels subjected to in-plane vertical and lateral loads. Basaran et al. [17] conducted a study whose purpose is the improvement of the behaviors of walls constructed with masonry bricks using reinforced plaster mortars. Calio and Panto [18] used a macroelement modelling approach of infilled frame structures. Validation of macroelement models and cost analysis for unreinforced and confined masonry buildings were considered by Marques and Lourenco [19]. Asteris et al. [20] used a macromodelling approach for the analysis of infilled frame structures. Berardi [21] used a micromechanical procedure in order to evaluate the initiation of damage and failure of masonry with in-plane loads. Ridwan et al. [22] proposed a new simplified formula for the calculation of the equivalent modulus of elasticity of masonry structures. Panto et. al. [23] used a 3D discrete macroelement for modelling the out-ofplane behaviour of infilled frames. Yang et al. [24] proposed 


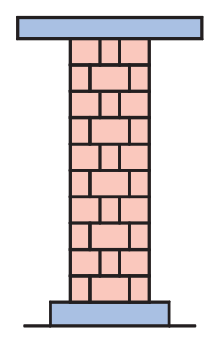

(a)

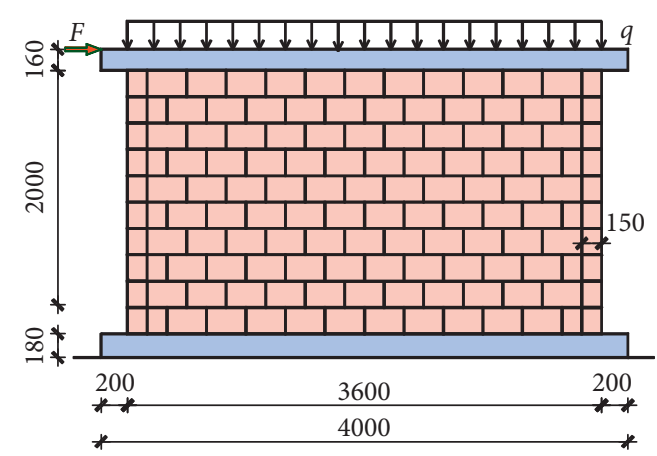

(b)

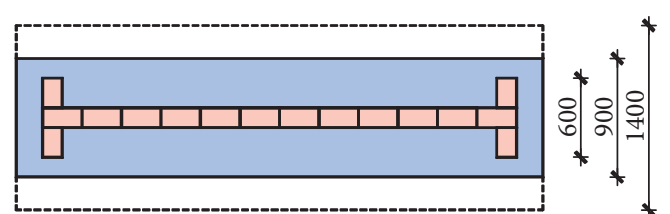

(c)

FIGURE 3: Geometry and load of the ETH Zürich walls tested by Ganz and Thürlimann [27]: (a) side view; (b) front view; (c) horizontal section.

TABLE 1: W1 and W2 material properties [27].

\begin{tabular}{lc}
\hline$h$ direction & $v$ direction \\
\hline$E_{m}^{h}=2460 \mathrm{MPa}$ & $E_{m}^{v}=5460 \mathrm{MPa}$ \\
$v_{m}^{h}=0.18$ & $v_{m}^{v}=0.18$ \\
$G^{v h}=1130 \mathrm{MPa}$ & $G^{h v}=1130 \mathrm{MPa}$ \\
$f_{m t}^{h}=0.05 \mathrm{MPa}$ & $f_{m t}^{v}=0.28 \mathrm{MPa}$ \\
$f_{m c}^{h}=1.87 \mathrm{MPa}$ & $f_{m c}^{v h}=7.61 \mathrm{MPa}$ \\
\hline
\end{tabular}

TABLE 2: Basic parameters of masonry for the presented numerical model.

\begin{tabular}{lc}
\hline$h$ direction & $v$ direction \\
\hline$f_{m t}^{h}=0.05 \mathrm{MPa}$ & $f_{m t}^{v}=0.28 \mathrm{MPa}$ \\
$f_{m c}^{h}=1.87 \mathrm{MPa}$ & $f_{m c}^{v h}=7.61 \mathrm{MPa}$ \\
$E_{m}^{h}=2460 \mathrm{MPa}$ & $E_{m}^{v}=5460 \mathrm{MPa}$ \\
$v_{m}^{h}=0.18$ & $v_{m}^{v}=0.18$ \\
$\varepsilon_{m o}^{h}=0.00002$ & $\varepsilon_{m o}^{v}=0.00005$ \\
$\varepsilon_{m t}^{h}=10 \varepsilon_{m o}^{h}$ & $\varepsilon_{m t}^{v}=10 \varepsilon_{m o}^{v}$ \\
$\varepsilon_{m c}^{h}=-0.002$ & $\varepsilon_{m c}^{v}=-0.004$ \\
\hline
\end{tabular}

an equation for calculating the shear strength of masonry with precast concrete antishear blocks based on the experimental results. Yang et al. [25] proposed a simple and rational stress-strain relationship model applicable to brick masonry under compression.

However, there is still no such numerical model for the analysis of masonry structures that would be appropriate for extensive engineering applications, i.e., which would be simple enough and able to simulate the main nonlinear effects of the masonry structures. Hence, such a model should adequately simulate not only the nonlinear behaviour and anisotropy of masonry but also the real behaviour of reinforced concrete elements and soil-structure coupled systems.

In this paper, a quite simple numerical model for analysis of planar unreinforced and confined masonry structures is briefly described. The model can simulate the main nonlinear effects of masonry, reinforced concrete, and soil, as well as the soil-structure interaction and large displacements of the structure. The model is intended for engineering applications. The emphasis on improving the constitutive masonry model developed by Radnić et al. [26] is the

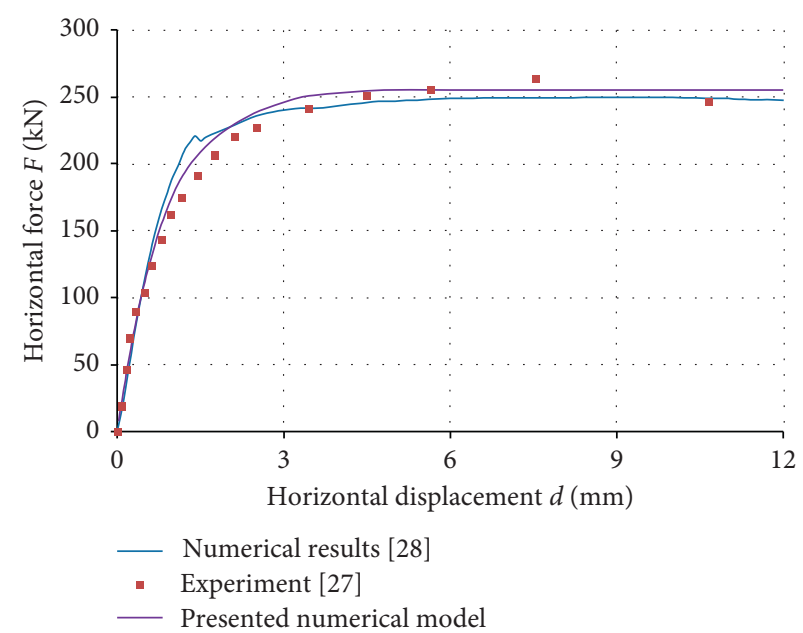

(a)

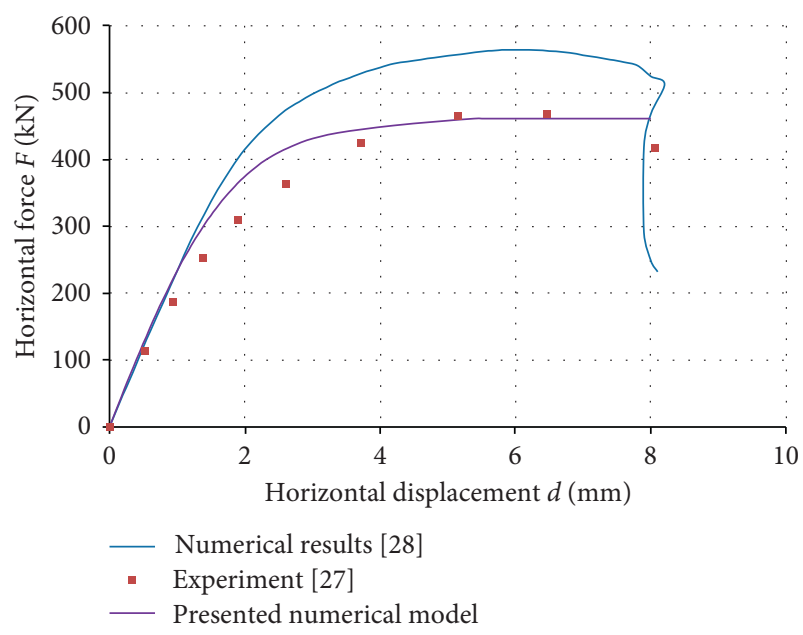

(b)

FIgURE 4: Horizontal displacement of the top of the wall: (a) wall W1; (b) wall W2.

primary purpose of this paper, with the intention of modelling the masonry anisotropy. The directions of the masonry anisotropy correspond to the horizontal and vertical joints of the masonry units. Corresponding stiffness, strength, and limit strains of masonry are modelled for the main direction 


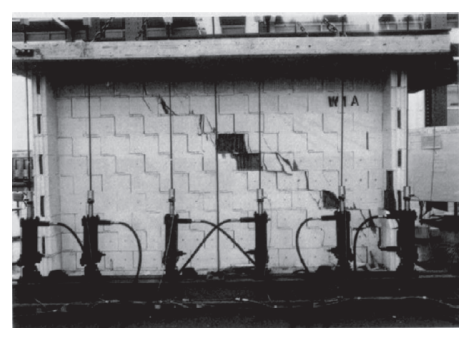

(a)

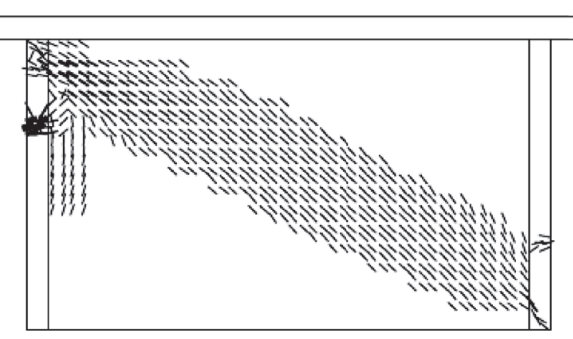

(b)

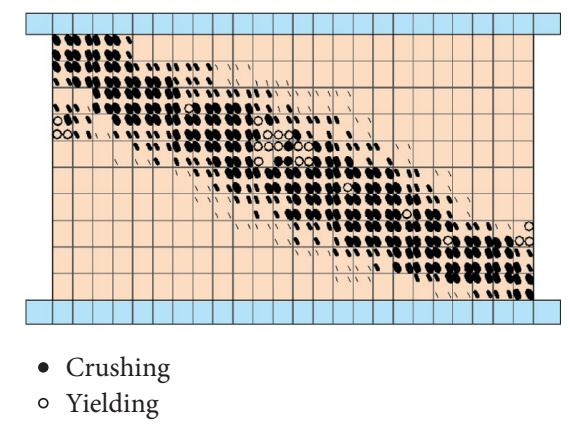

(c)

FIGURE 5: Crack patterns for wall W1 at a displacement of $12 \mathrm{~mm}$ : (a) experiment [27]; (b) numerical results [28]; (c) presented numerical model.

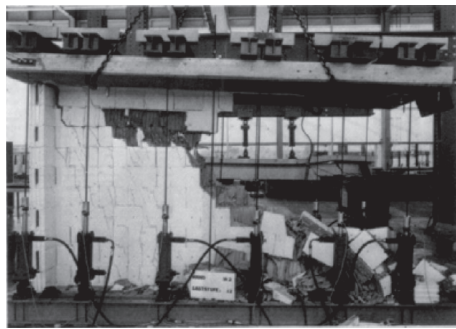

(a)

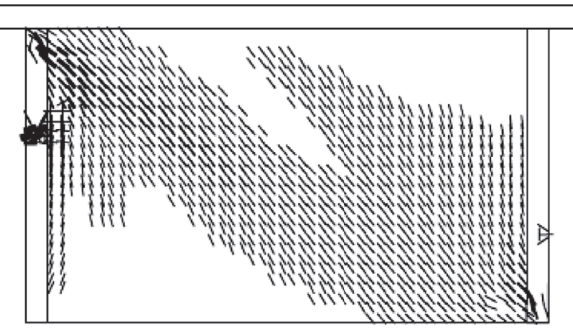

(b)

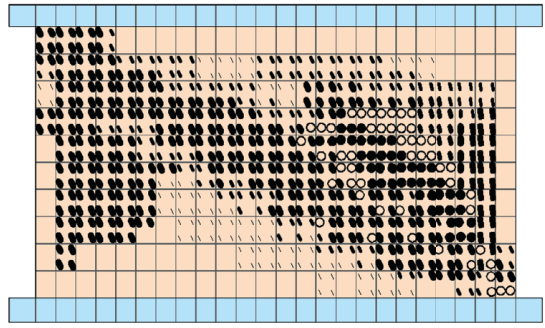

- Crushing

- Yielding

(c)

FIGURE 6: Crack patterns for wall W2 at displacement of $8 \mathrm{~mm}$ : (a) experiment [27]; (b) numerical results [28]; (c) presented numerical model.
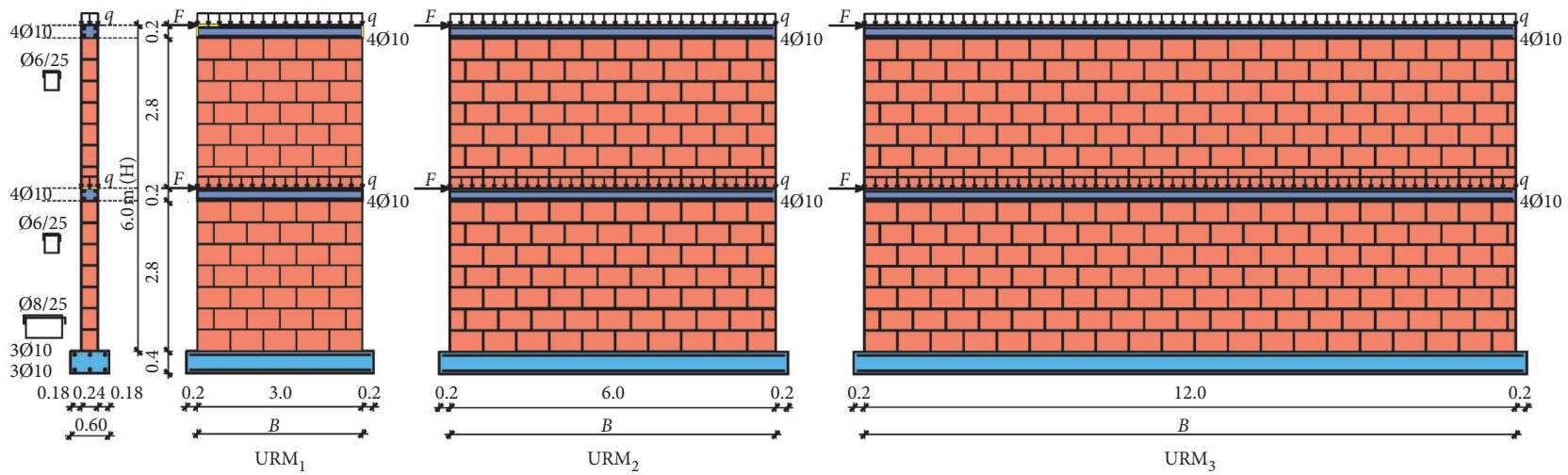

(a)
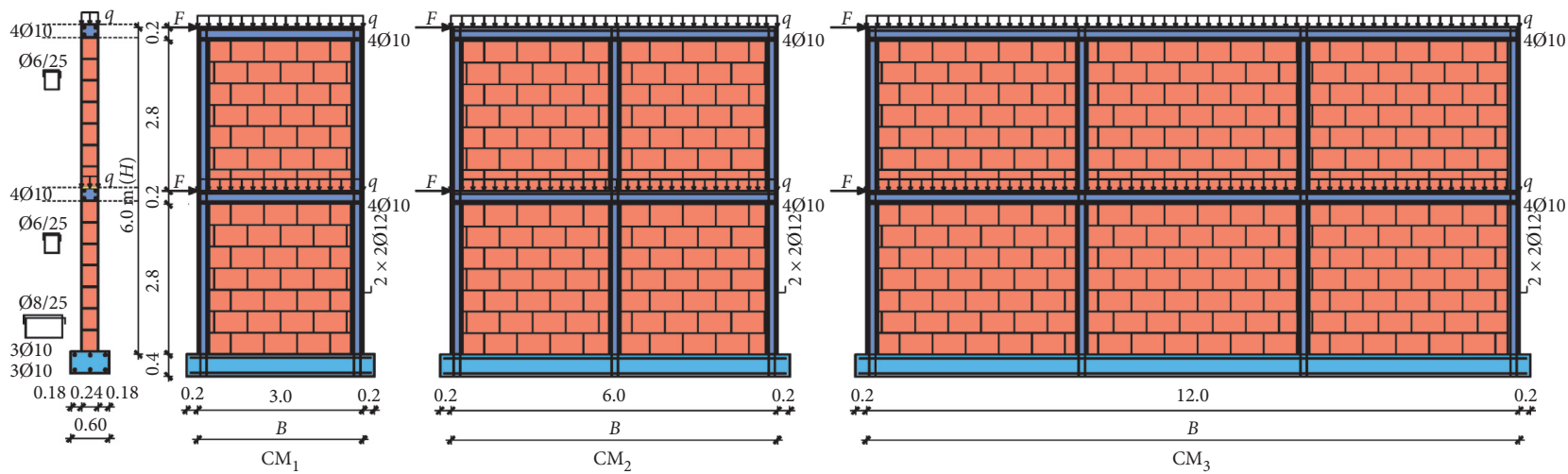

(b)

Figure 7: Analysed masonry walls: (a) unreinforced masonry walls; (b) confined masonry walls. 

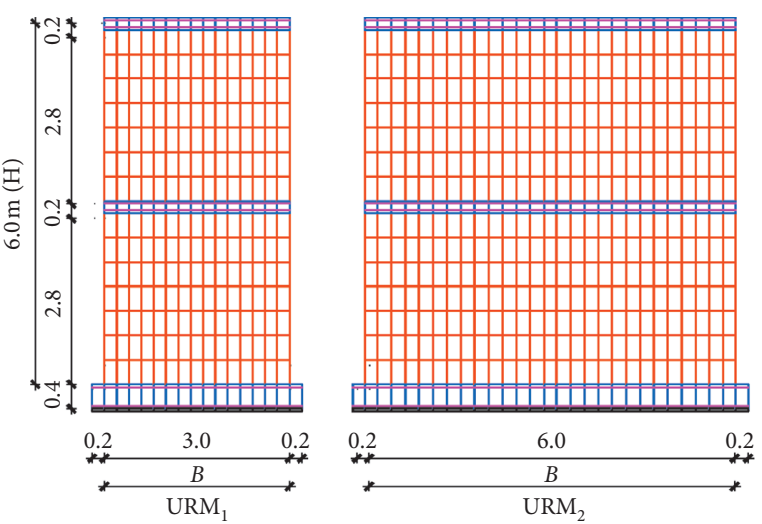

- 2D elements (concrete)
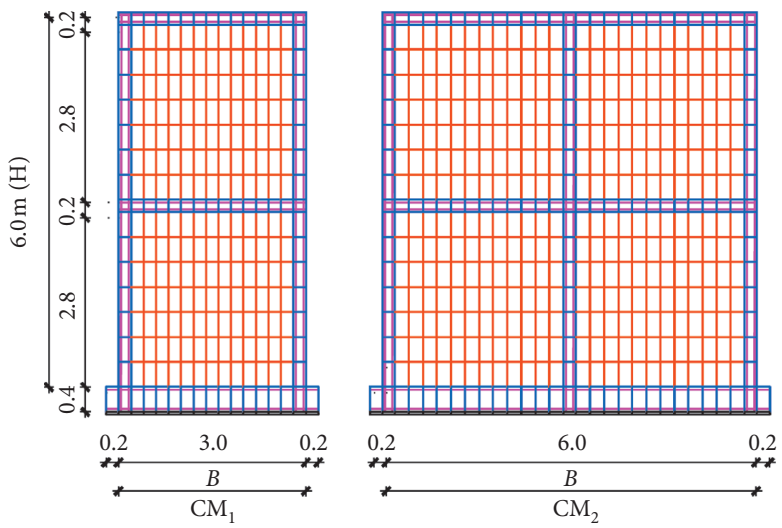

- 2D elements (concrete)

- 2D elements (masonry)

FIGURE 8: Finite element discretization of the walls: (a) unreinforced masonry walls; (b) confined masonry walls.

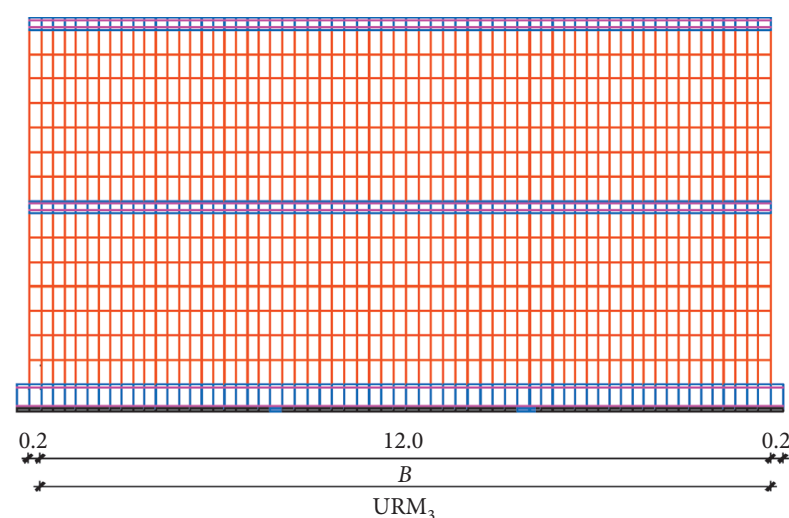

- 1D bar elements (reinforcement)

- Contact elements

(a)

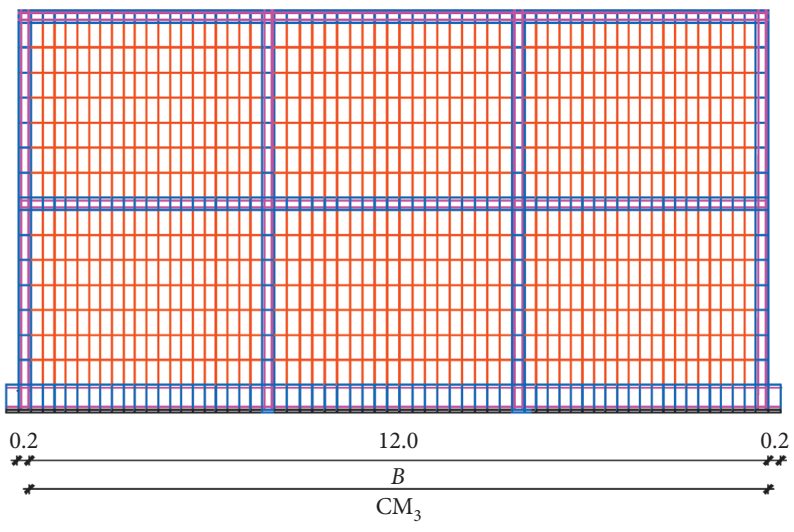

— 1D bar elements (reinforcement)

- Contact elements

(b)

TABle 3: Adopted basic material parameters for masonry.

\begin{tabular}{|c|c|c|c|c|c|c|c|c|c|}
\hline \multirow{2}{*}{ Parameter } & \multirow{2}{*}{ Unit } & \multicolumn{4}{|c|}{ Stiff masonry } & \multicolumn{4}{|c|}{ Soft masonry } \\
\hline & & $c_{a}=0.2$ & $c_{a}=0.4$ & $c_{a}=0.6$ & $c_{a}=1.0$ & $c_{a}=0.2$ & $c_{a}=0.4$ & $c_{a}=0.6$ & $c_{a}=1.0$ \\
\hline Elasticity modulus $E_{m}^{v}$ & $\mathrm{MPa}$ & 5000 & 5000 & 5000 & 5000 & 1000 & 1000 & 1000 & 1000 \\
\hline Elasticity modulus $E_{m}^{h}$ & $\mathrm{MPa}$ & 1000 & 2000 & 3000 & 5000 & 200 & 400 & 600 & 1000 \\
\hline Shear modulus $G_{m}$ & $\mathrm{MPa}$ & 793.6 & 1315.7 & 1685.4 & 2173.9 & 158.7 & 263.2 & 337.1 & 434.8 \\
\hline Compressive strength $f_{m c}^{v}$ & $\mathrm{MPa}$ & 5.0 & 5.0 & 5.0 & 5.0 & 1.0 & 1.0 & 1.0 & 1.0 \\
\hline Compressive strength $f_{m c}^{h c}$ & $\mathrm{MPa}$ & 1.0 & 2.0 & 3.0 & 5.0 & 0.2 & 0.4 & 0.6 & 1.0 \\
\hline Tensile strength $f_{m t}^{v}$ & $\mathrm{MPa}$ & 0.15 & 0.15 & 0.15 & 0.15 & 0.03 & 0.03 & 0.03 & 0.03 \\
\hline Tensile strength $f_{m t}^{h t}$ & $\mathrm{MPa}$ & 0.03 & 0.06 & 0.09 & 0.15 & 0.006 & 0.012 & 0.018 & 0.03 \\
\hline
\end{tabular}

TABLE 4: Adopted basic material parameters for concrete, reinforcement, and contact elements.

\begin{tabular}{lcccc}
\hline Parameters & Unit & Concrete & Reinforcement & Contact elements \\
\hline Elasticity modulus & $\mathrm{MPa}$ & 30500 & 210000 & 30500 \\
Shear modulus & $\mathrm{MPa}$ & 13260 & & 560 \\
Compressive strength & $\mathrm{MPa}$ & 25 & 560 & 25 \\
Tensile strength & $\mathrm{MPa}$ & 2.5 & 0 \\
\hline
\end{tabular}



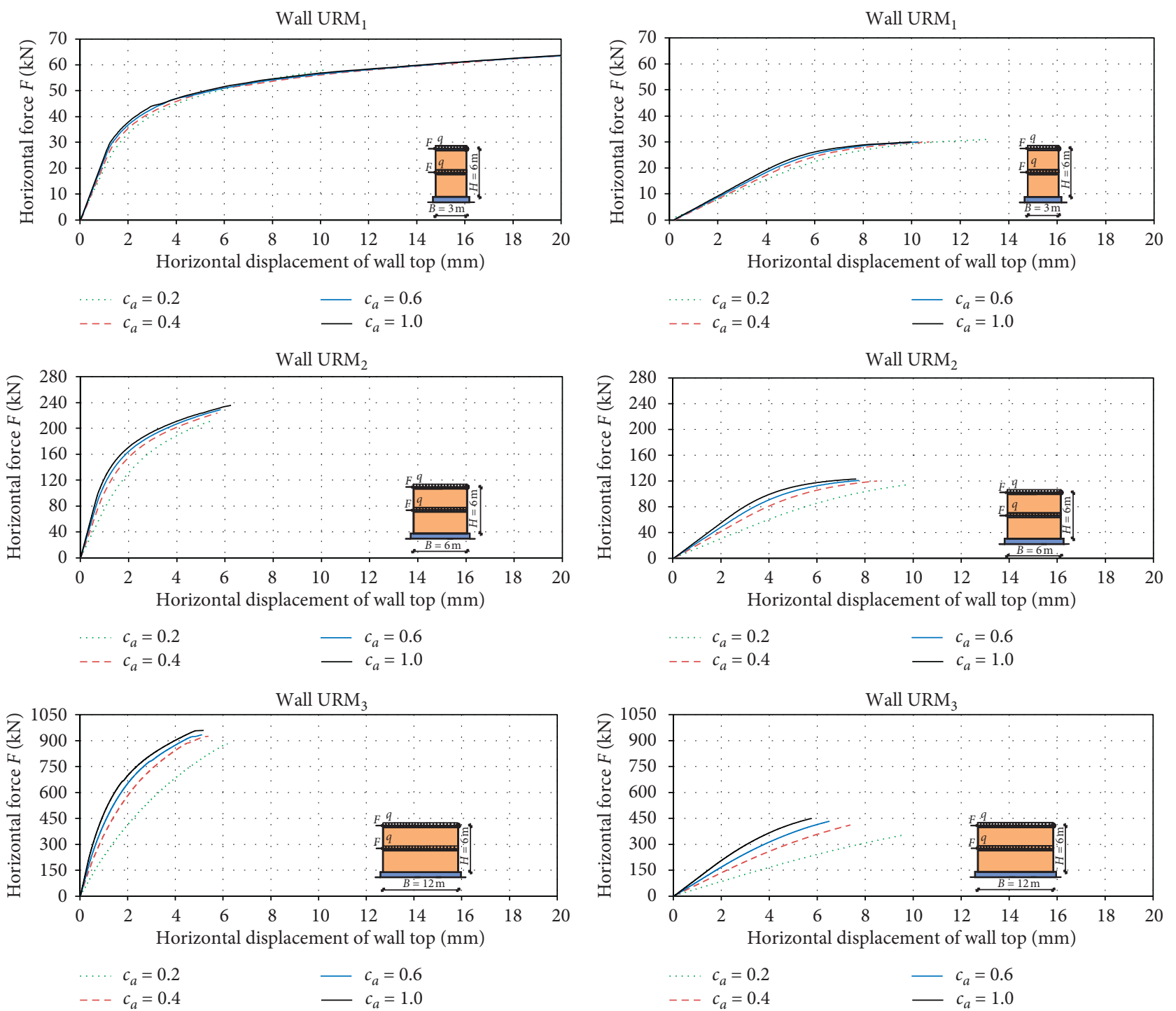

(a)

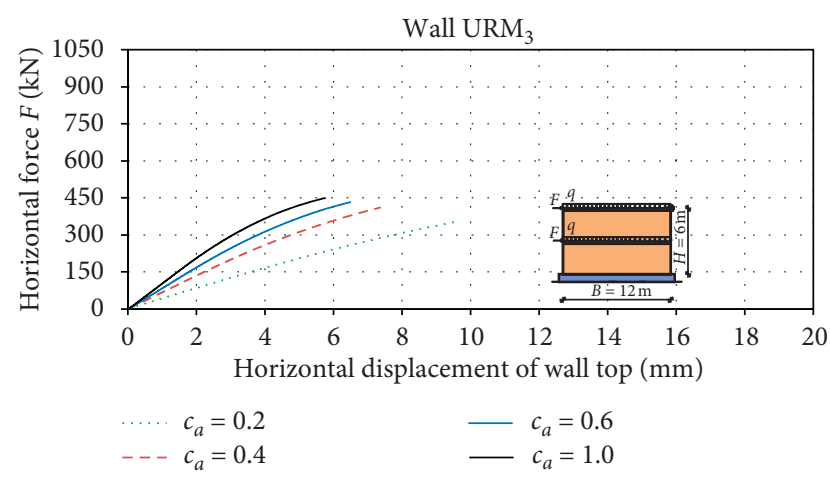

(b)

Figure 9: Horizontal displacement of the top of unreinforced masonry walls: (a) stiff masonry; (b) soft masonry.

of anisotropy. Criteria for yielding (limit bearing capacity) and failure (collapse) of masonry are separately defined for normal stresses only and for normal and shear stresses. The yielding of masonry in the compression and cracking of masonry in tension are modelled, as well as the opening and closing of smeared cracks at repeated loading. Constitutive models for reinforced concrete, soil, and contact elements were taken from the study of Radnić et al. [26]. The updated numerical model is verified on the experimental test [27] and numerical results [28].

Using the updated numerical model, the behaviour and bearing capacity of unreinforced and confined two-story masonry walls with different lengths, qualities of masonry, and coefficients of anisotropy are analysed under horizontal static forces. It is assumed that the wall foundations stand on a rigid base with the possibility of uplifting. The walls were loaded with a constant vertical load and various horizontal forces at the floor levels. The force successively increased until wall failure. The effect of masonry anisotropy on the behaviour and limit bearing capacity of the walls is studied. The conclusions of the analysis are presented at the end of this paper.

\section{Numerical Model}

A detailed description of the basic finite element numerical model can be found in the study of Radnić et al. [26]. In this paper, the constitutive model of masonry was extended to include the effect of anisotropy of masonry and a more adequate model of shear effect on bearing capacity of masonry.

A simplified macromodel for masonry is adopted that is intended for practical applications and able to simulate the main nonlinear effects of this material. At the macrolevel, the masonry is approximated by a representative material whose mechanical properties can adequately describe the actual 

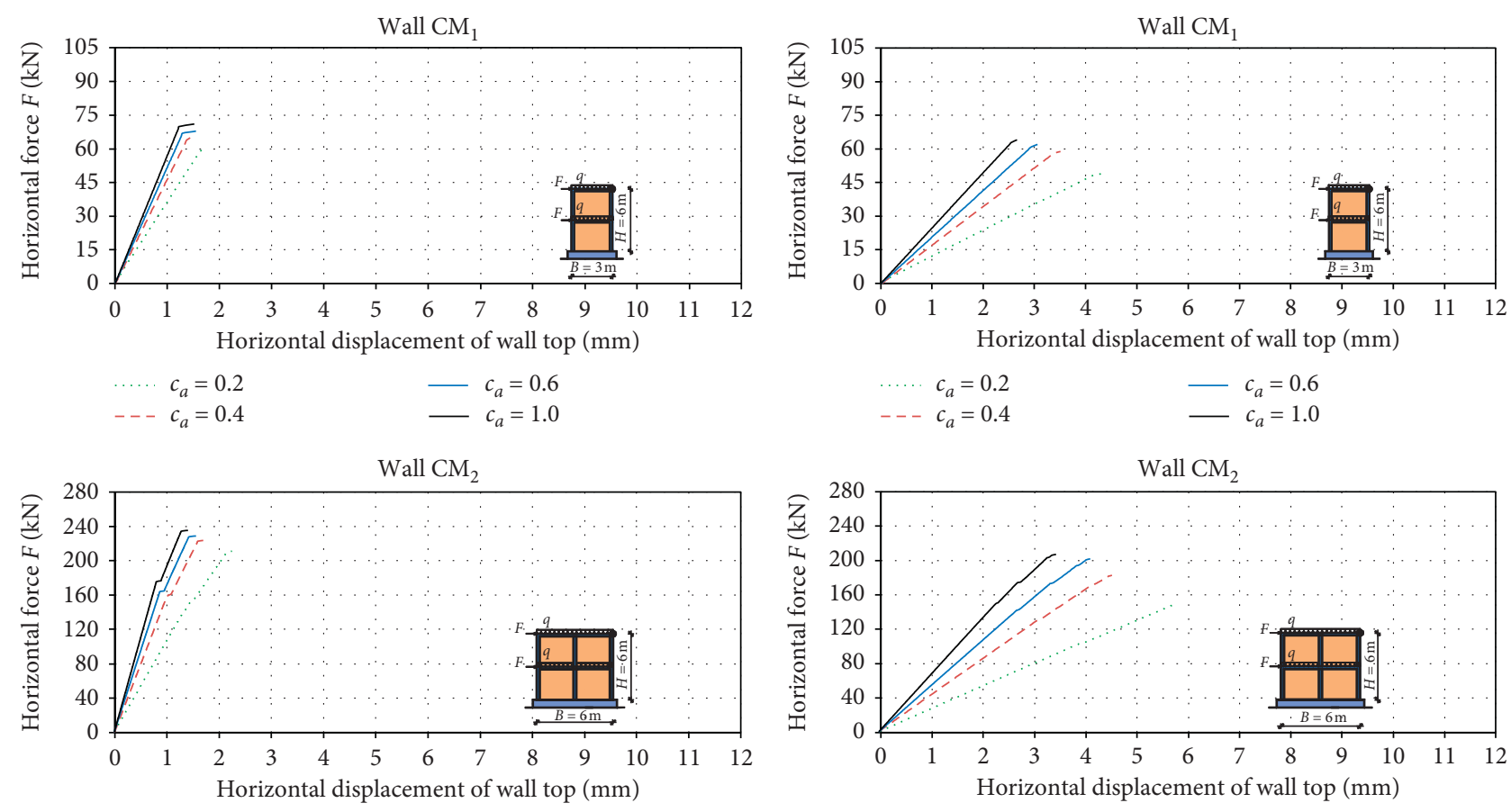

$$
\begin{array}{ll}
c_{a}=0.2 \\
--c_{a}=0.4 \quad-c_{a}=0.6 \\
c_{a}=1.0
\end{array}
$$

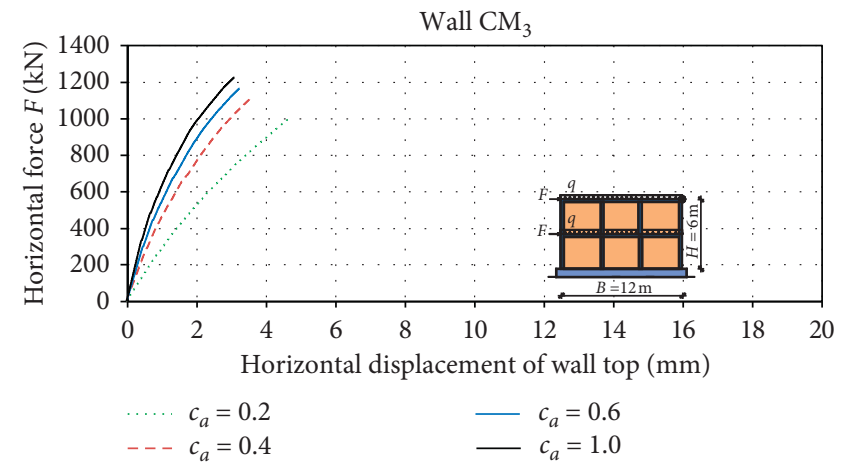

(a)

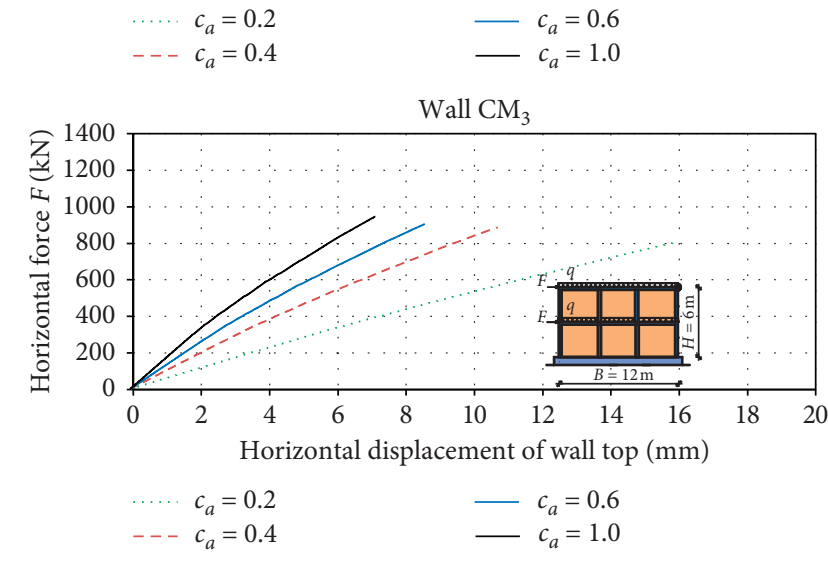

(b)

Figure 10: Horizontal displacement of the top of confined masonry walls: (a) stiff masonry; (b) soft masonry.

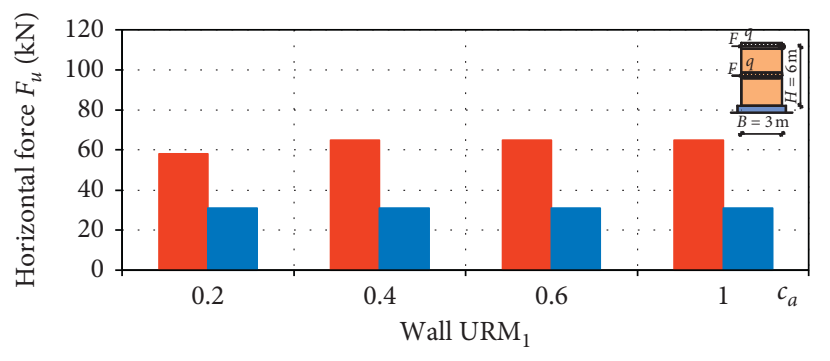

- Stiff masonry

- Soft masonry

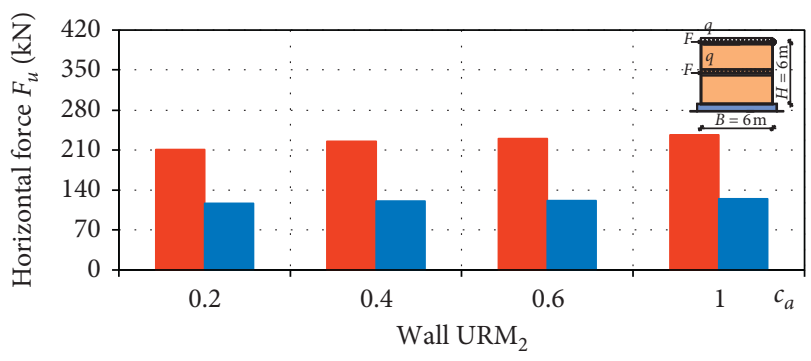

- Stiff masonry - Soft masonry

(a)

(b)

Figure 11: Continued. 


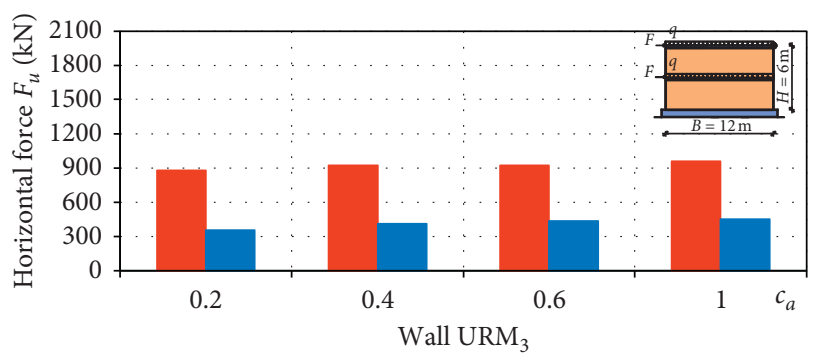

- Stiff masonry

- Soft masonry

(c)

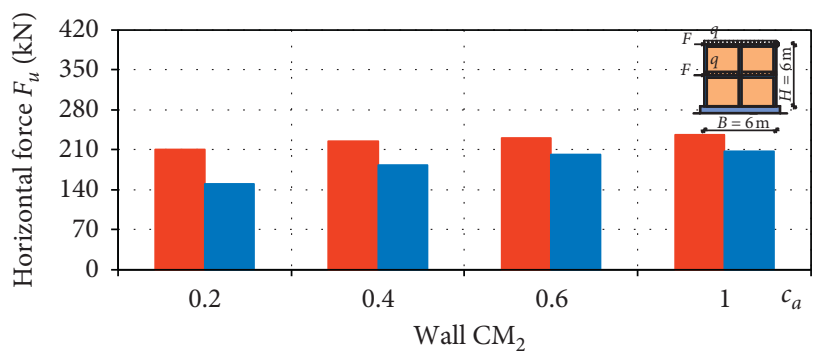

- Stiff masonry

- Soft masonry

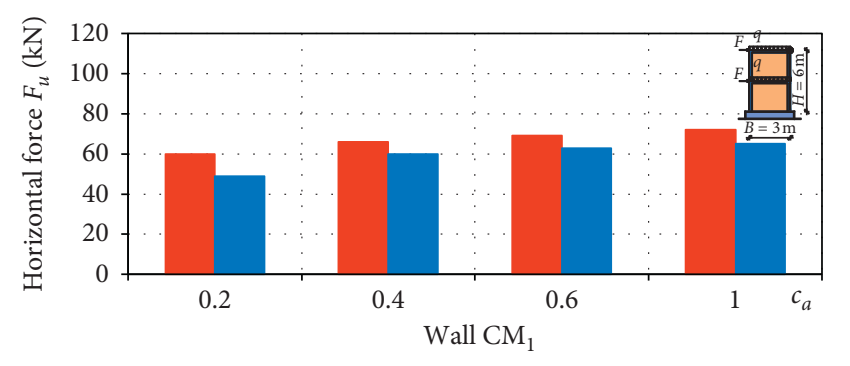

- Stiff masonry

- Soft masonry

(d)

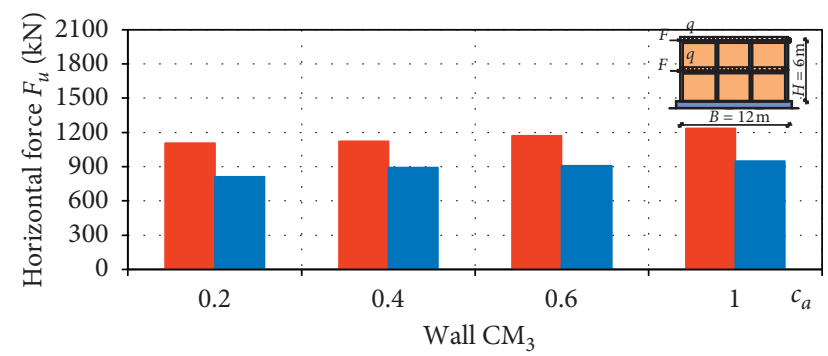

- Stiff masonry

- Soft masonry

(e)

FIGURE 11: Relation between limit force $F_{u}$ and coefficient of anisotropy $c_{a}$. (a) $\mathrm{URM}_{1}$; (b) Wall URM $\mathrm{UR}_{2}$ (c) Wall URM $\mathrm{UR}_{3}$ (d) Wall CM . (e) Wall $\mathrm{CM}_{2}$. (f) Wall $\mathrm{CM}_{3}$.

complex masonry properties. This approach allows the use of large finite elements (rough discretization) and significantly reduces the number of unknown variables in comparison with a micromodel of masonry (i.e., this approach rapidly accelerates the structure analysis).

An orthotropic model for masonry is assumed, which is analogous to a previously developed model by Smilovic et al. [29] for masonry exposed to dynamic loading. The main directions of the orthotropy are horizontal $(h)$ and vertical $(v)$, which is the usual case in real masonry walls. For each direction of orthotropy, different compressive strengths of masonry $\left(f_{m c}^{h}, f_{m c}^{v}\right)$, tensile strengths $\left(f_{m t}^{h}, f_{m t}^{v}\right)$, moduli of elasticity $\left(E_{m}^{v}, E_{m}^{h}\right)$, limit compressive strains $\left(\varepsilon_{m c}^{h}, \varepsilon_{m c}^{v}\right)$, and limit tensile strains $\left(\varepsilon_{m o}^{h}, \varepsilon_{m o}^{v}, \varepsilon_{m t}^{h}, \varepsilon_{m t}^{v}\right)$ can be defined. Wherein, $\varepsilon_{m o}^{h}, \varepsilon_{m o}^{v}$ denote strains at the cracks occurrence $\left(\varepsilon_{m o}^{h}=f_{m t}^{h} / E_{m}^{h}, \varepsilon_{m o}^{v}=f_{m t}^{v} / E_{m}^{v}\right)$, and $\varepsilon_{m t}^{h}, \varepsilon_{m t}^{v}$ are the fictitious strains after which the masonry has no tensile stiffness. The coefficient of anisotropy (orthotropy) is defined by

$$
c_{a}=\frac{E_{m}^{h}}{E_{m}^{v}}=\frac{f_{m c}^{h}}{f_{m c}^{v}}=\frac{f_{m t}^{h}}{f_{m t}^{v}} .
$$

It should be noted that

$$
E_{m}^{v} v_{m}^{v}=E_{m}^{h} v_{m}^{h}
$$

where $v_{m}^{h}$ and $v_{m}^{v}$ are Poisson's ratios in the horizontal and vertical directions, respectively.

The criteria of limit bearing capacity of masonry were considered separately for normal stresses only and for normal and corresponding shear stresses. Graphical presentations of the adopted orthotropic constitutive masonry model in compression and tension are given in Figure 1, where $\sigma_{m}^{h}$ and $\sigma_{m}^{v}$ are the normal stresses.

As shown in Figure 1, the effect of biaxial compressive stresses on the limit bearing capacity of masonry is disregarded. As the model is intended for practical use, a small number of parameters were assumed that can be easily determined from classical uniaxial tests (strengths, limit strains, and modulus of elasticity).

In biaxial compression, elastic-plastic behaviour with linear unloading is assumed. Elastic behaviour is assumed when the stresses in masonry are smaller than the uniaxial compressive strength. Then completely plastic behaviour is assumed. The crushing of masonry is assumed when the strain of masonry reaches the maximum compressive strain from the uniaxial test.

In biaxial tension, elastic behaviour is adopted until the tensile strength of masonry is reached. Then, it is assumed that smeared cracks occur in the plane perpendicular to the direction of tensile stresses. The tensile stiffness of the cracked masonry is simulated by a gradual decrease in the tensile stress components perpendicular to the crack plane in accordance with the stress-strain relation from the uniaxial tension test.

The opening and closing of cracks are modelled. The transfer of compressive stress across a fully closed crack is modelled as in masonry without cracks. After crack reopening, the tensile stiffness of the cracked masonry perpendicular to the crack plane is taken to be zero. The shear stiffness of the cracked masonry is modelled by reducing the shear modulus depending on the value of the tensile masonry strain perpendicular to the crack plane. 

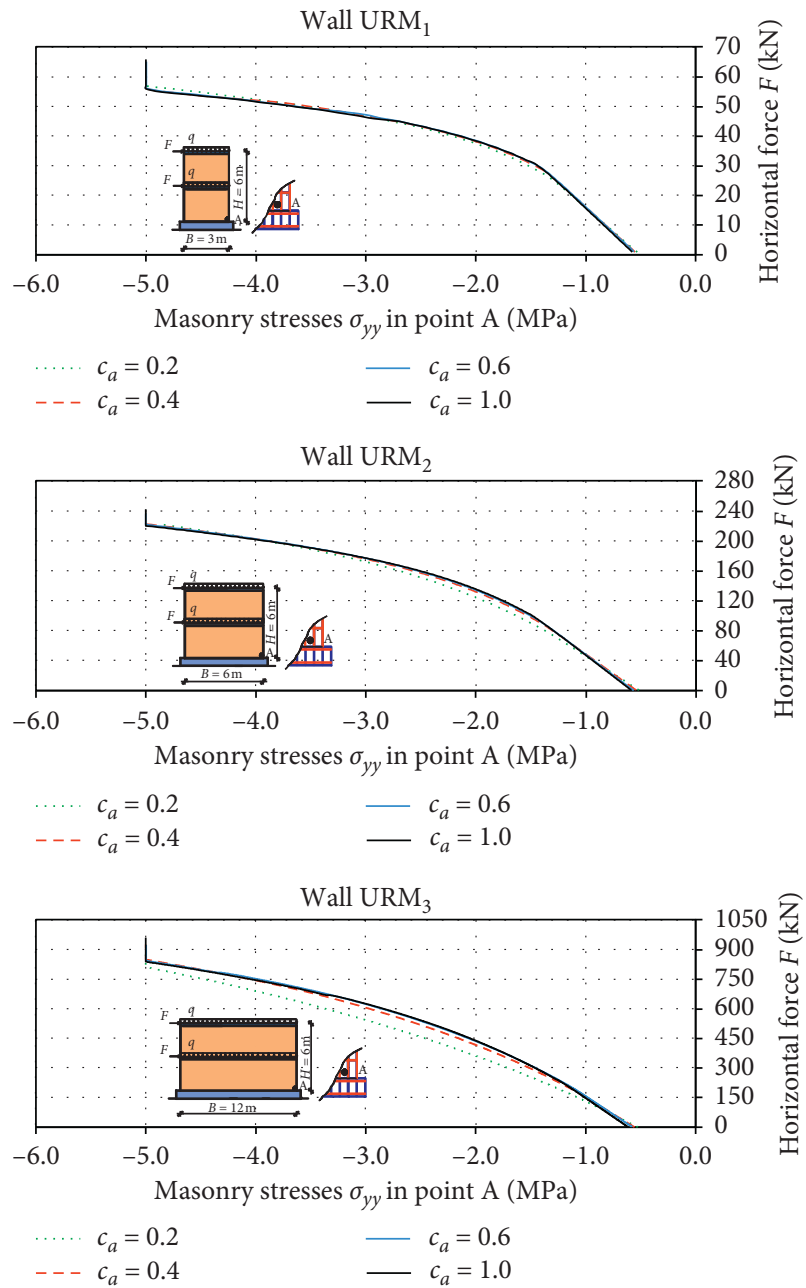

(a)

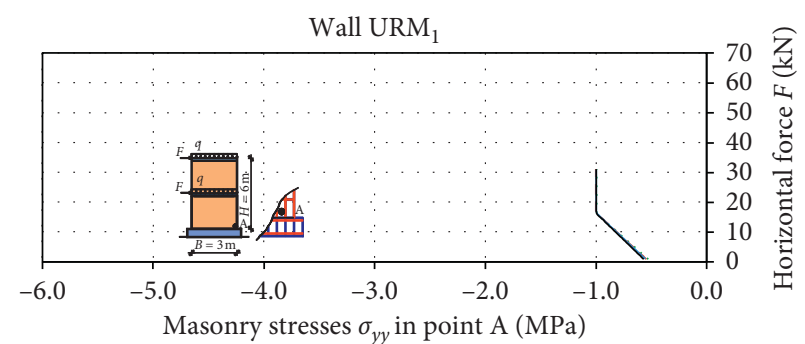

$\begin{array}{ll}\cdots c_{a}=0.2 \\ -c_{a}=0.4 & -c_{a}=0.6 \\ -c_{a}=1.0\end{array}$

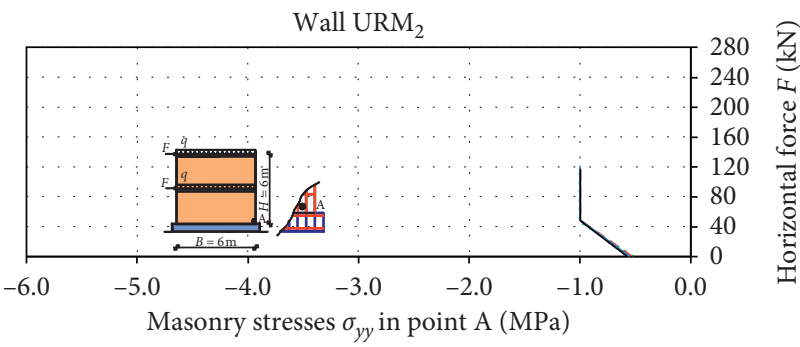

$\begin{array}{ll}\cdots & c_{a}=0.2 \\ -c_{a} & =0.4\end{array}$

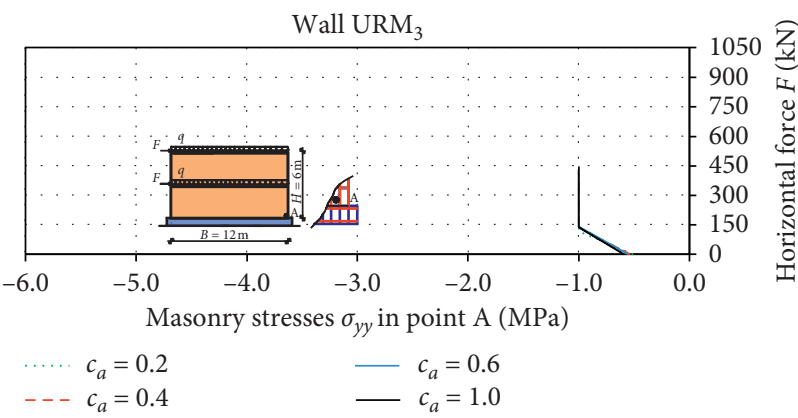

(b)

FIgURE 12: Vertical stresses in masonry in point A at the bottom of unreinforced masonry walls: (a) stiff masonry; (b) soft masonry.

In addition to tension (cracking) and compression (crushing), the collapse of the masonry due to shear stress is modelled. The criterion for the yielding and failure (collapse) of masonry under normal and shear stresses is defined according to Figure 2. The model is simple and includes the relation of normal and shear stresses/strains according to the circular equation. Therefore, the masonry yield criterion is defined in a function of stresses and the failure criterion as a function of strains. A simple relation between normal and shear stresses/strain was adopted for use in practical applications, where basic parameters of masonry are usually not experimentally determined.

The shear modulus of masonry $G_{\mathrm{m}}$ is given by

$$
G_{m}=\frac{1}{\left(\left(1+v_{m}^{h}\right) / E_{m}^{h}\right)+\left(\left(1+\nu_{m}^{v}\right) / E_{m}^{v}\right)} .
$$

The adopted isotropic concrete model in Section 4 is described in the study of Radnić et al. [26,30], which can simulate yielding of concrete in compression and cracking in tension. The adopted constitutive model for contact elements is described in the study of Radnić et al. [26], which can simulate separation and slippage on contact surface. The presented anisotropic masonry model or isotropic concrete model can be used for the soil model, with corresponding material parameters for soil.

\section{Validation of the Numerical Model}

The numerical model presented in Section 2, previously verified in its basic form [26], is validated based on the results of experimental tests at ETH Zürich by Ganz and Thürlimann [27] and numerical results by Lourenco [28]. The geometry and loading of walls W1 and W2 are presented in Figure 3. The experimentally determined material properties of the masonry are shown in Table 1 [27]. The walls were subjected to a uniform axial load followed by an incremental horizontal force $(F)$ at the top of the slab that caused a horizontal displacement $(d)$. The only difference between walls W1 and W2 is the initial axial force applied to the walls, which resulted in different behaviour and failure modes. The initial vertical load was $q=0.61 \mathrm{MPa}$ $(415 \mathrm{kN})$ for wall W1 and $q=1.91 \mathrm{MPa}(1287 \mathrm{kN})$ for wall W2. Wall W1 showed a ductile response with tensile and 


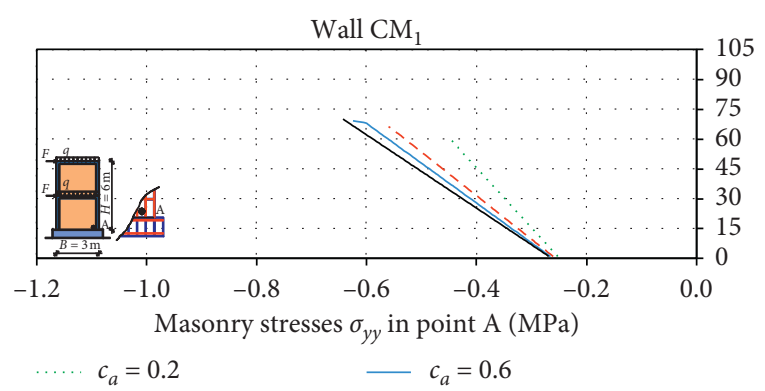

$$
-c_{a}=0.4 \quad-c_{a}=1.0
$$

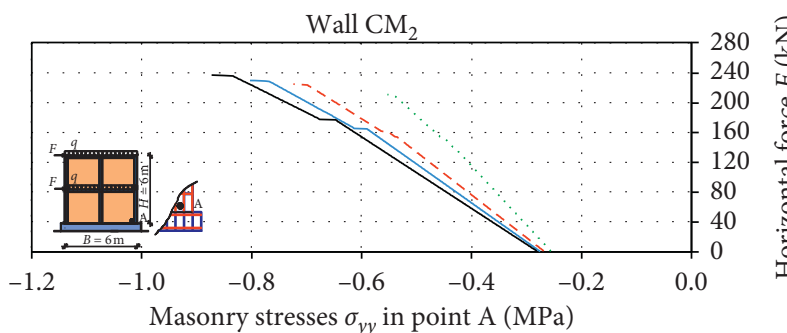

$$
\begin{aligned}
& \text { ….. } c_{a}=0.2 \quad-c_{a}=0.6 \\
& --c_{a}=0.4 \quad-c_{a}=1.0
\end{aligned}
$$

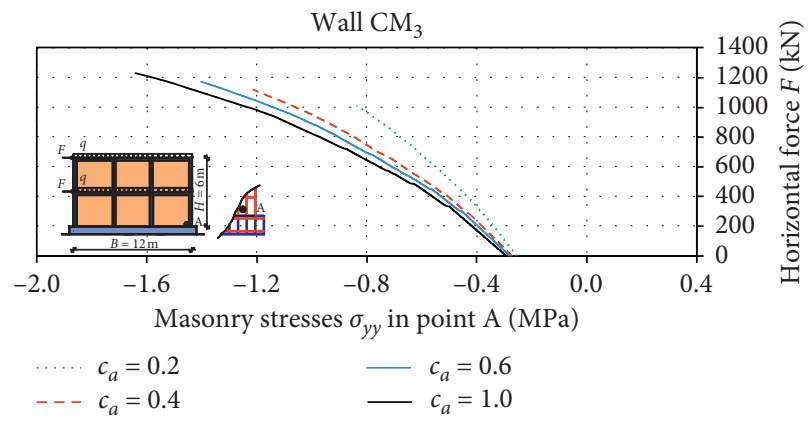

(a)
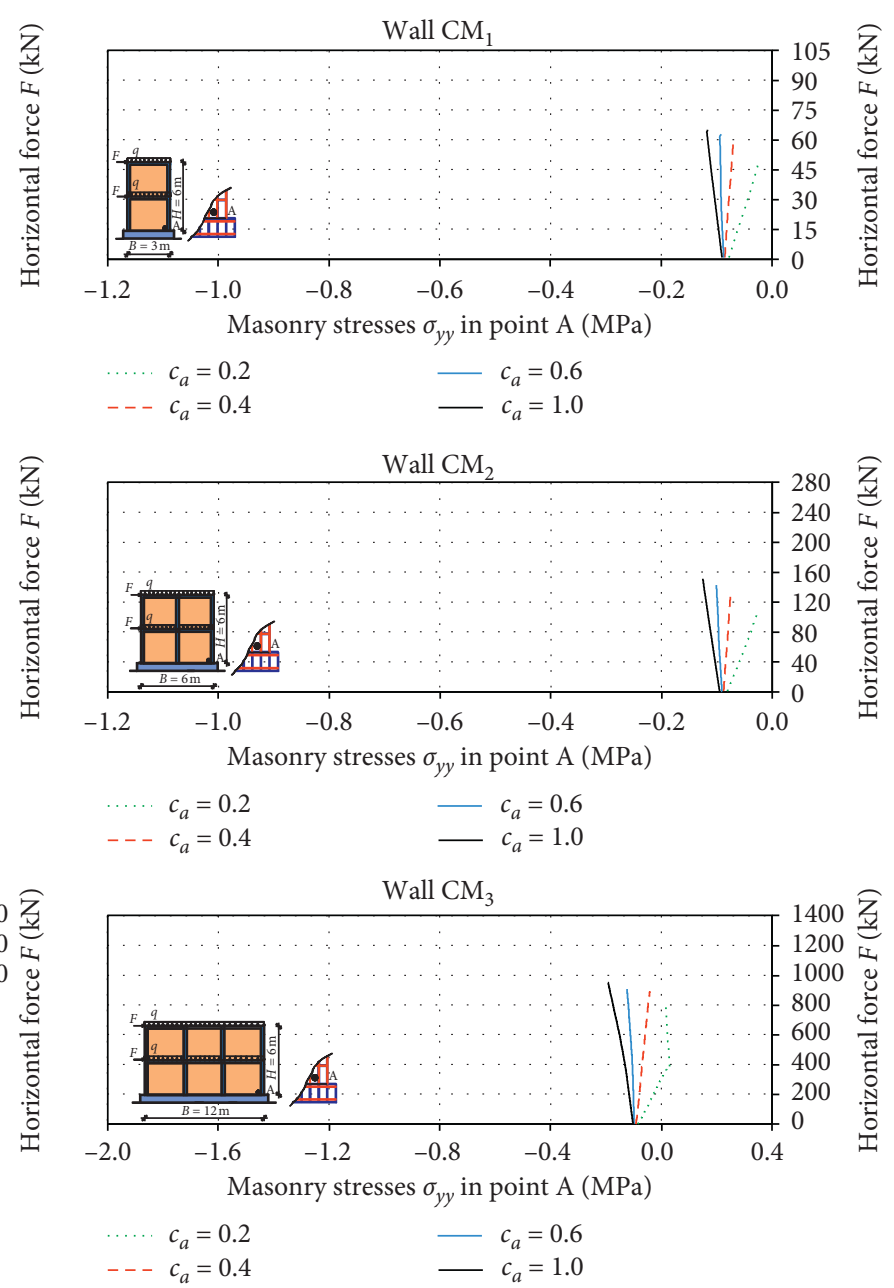

(b)

FIGURE 13: Vertical stresses in masonry in point A at the bottom of confined masonry walls: (a) stiff masonry; (b) soft masonry.

shear failure along the diagonal stepped cracks. The behaviour of wall W2 began with relative ductility and was followed by brittle cracking [27]. The adopted parameters of masonry for the presented numerical model are presented in Table 2.

Only some of the numerical results are presented. The experimentally determined force $(F)$ versus displacement $(d)$ is presented in Figure 4. The experimentally determined crack patterns for wall $\mathrm{W} 1$ at a displacement of $12.0 \mathrm{~mm}$ are shown in Figure 5. The numerical crack patterns for wall W2 at a displacement of $8.0 \mathrm{~mm}$ are presented in Figure 6 .

The numerical results of the presented numerical model are in good agreement with the experimental results of Ganz and Thürlimann [27] and the numerical results of Lourenco [28].

\section{Numerical Tests of the Anisotropy Effects on the Behaviour of Unreinforced and Confined Masonry Walls under Horizontal Static Load}

Using the presented numerical model, the effect of masonry anisotropy on behaviour of single two-story unreinforced and confined masonry walls of different lengths under horizontal static force was investigated. The reason for this is the fact that masonry blocks in practice usually have vertical cavities and generally different load bearing capacity and deformability in the vertical and horizontal directions. We believe that this study contributes to the article quality and that it can be useful for understanding the effects of masonry anisotropy in practice.

4.1. Basic Data of the Analysed Walls. Two-story unreinforced and confined masonry walls with different lengths $B$ $(3 \mathrm{~m}, 6 \mathrm{~m}$, and $12 \mathrm{~m}$ ) were analysed (Figure 7). All walls were $0.24 \mathrm{~m}$ thick with $0.6 \mathrm{~m}$ wide concrete foundations. The foundations were reinforced with $3 \emptyset 10$ longitudinal bars in the upper and bottom zones and $\varnothing 8$ transverse stirrups with $250 \mathrm{~mm}$ spacing. The tie beams were reinforced with $4 \varnothing 10$ bars and tie columns with $4 \varnothing 12$ bars. The stirrups of the tie beams and tie columns were Ø6 at a $250 \mathrm{~mm}$ spacing.

4.2. Finite Element Discretization and Adopted Material Parameters. Finite element discretization of the walls is 

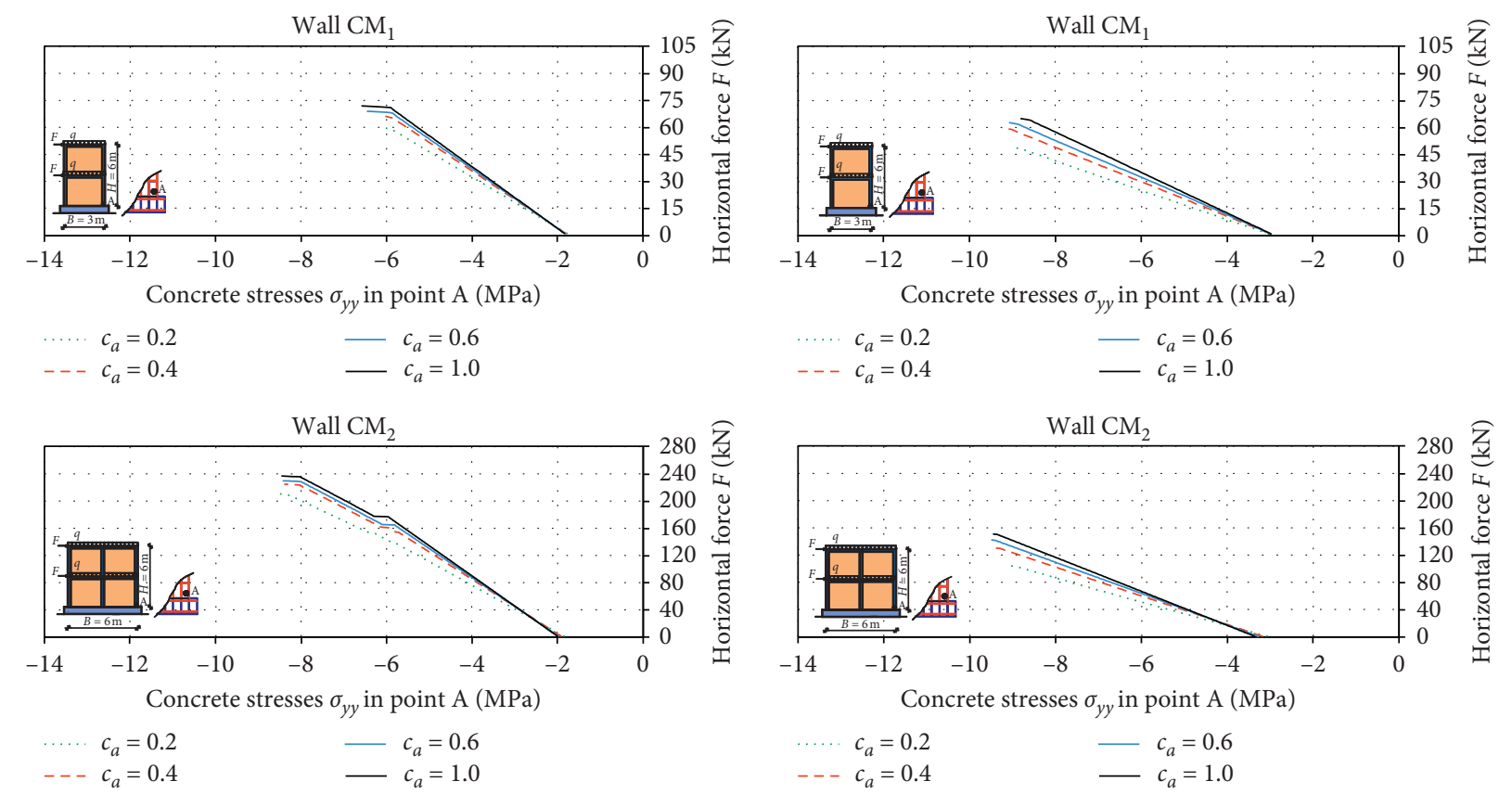

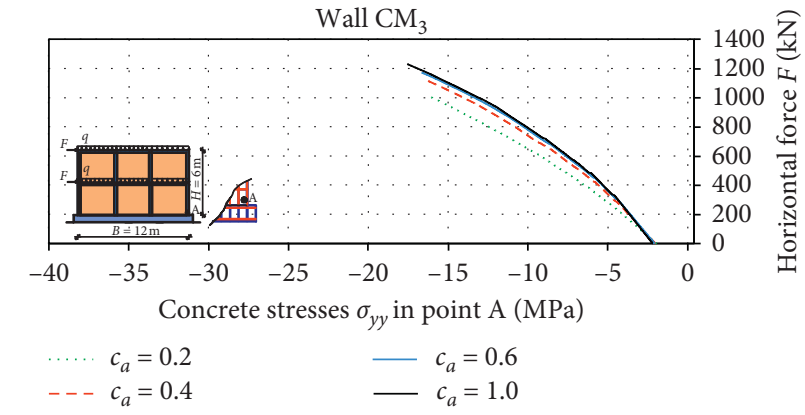

(a)

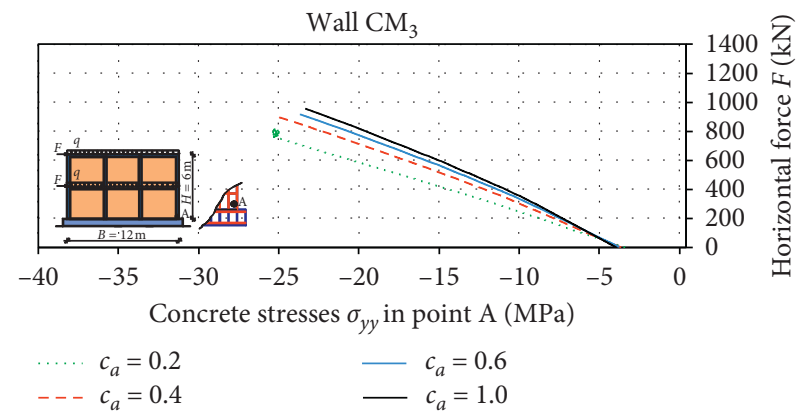

(b)

FIGURE 14: Vertical stresses in concrete in point A at the bottom of confined masonry walls: (a) stiff masonry; (b) soft masonry.

presented in Figure 8. It is assumed that the wall foundation stands on a rigid base with the possibility of uplifting. For this purpose, contact elements are placed below the foundations. Masonry with high strength and stiffness (stiff masonry) and masonry with low strength and stiffness (soft masonry) were considered. The adopted basic material parameters of the masonry (modulus of elasticity, shear modulus, compressive strength, and tensile strength) for the considered coefficient of anisotropy $c_{a}$ are shown in Table 3. The effect of shear stresses on the bearing capacity of masonry is not included (model according to Figure 2) in the performed analysis of masonry walls for clarity of presentation of the anisotropy effect of masonry under normal stresses only.

The walls were assumed to be in a plane-stress state. A rather rough finite element mesh was used, which should not affect the conclusions of the study. 8-node concrete elements and 3-node reinforcement elements were used. Full compatibility of displacement at the function of concrete and reinforcement was assumed. An elastic-fully plastic model of concrete in pressure was used. A smeared cracks model for concrete in tension was adopted. The mechanism of opening and closing of cracks in concrete and the tensile and shear stiffness of cracked concrete are modelled. Contact elements were taken at the bottom of the foundation.

The adopted basic material parameters of concrete, reinforcement, and contact elements are shown in Table 4. First, the initial displacements and internal stresses for the dead weight and vertical load $q$ of the walls were calculated. Then, the walls were incrementally loaded with horizontal force $F$ at the floor levels until wall failure.

4.3. Numerical Results. Some results of the numerical analysis performed for unreinforced and confined masonry walls with stiff and soft masonry are presented in Figures 9-15. When evaluating the presented diagrams, it should be borne in mind that the foundation lifting on the tensile side of the wall was modelled and that, in many cases, there was a loss of stability of the wall due to its overturning and not to wall collapse due to excess limit stresses/strains in masonry, concrete, or reinforcement (especially with narrower confined walls). 

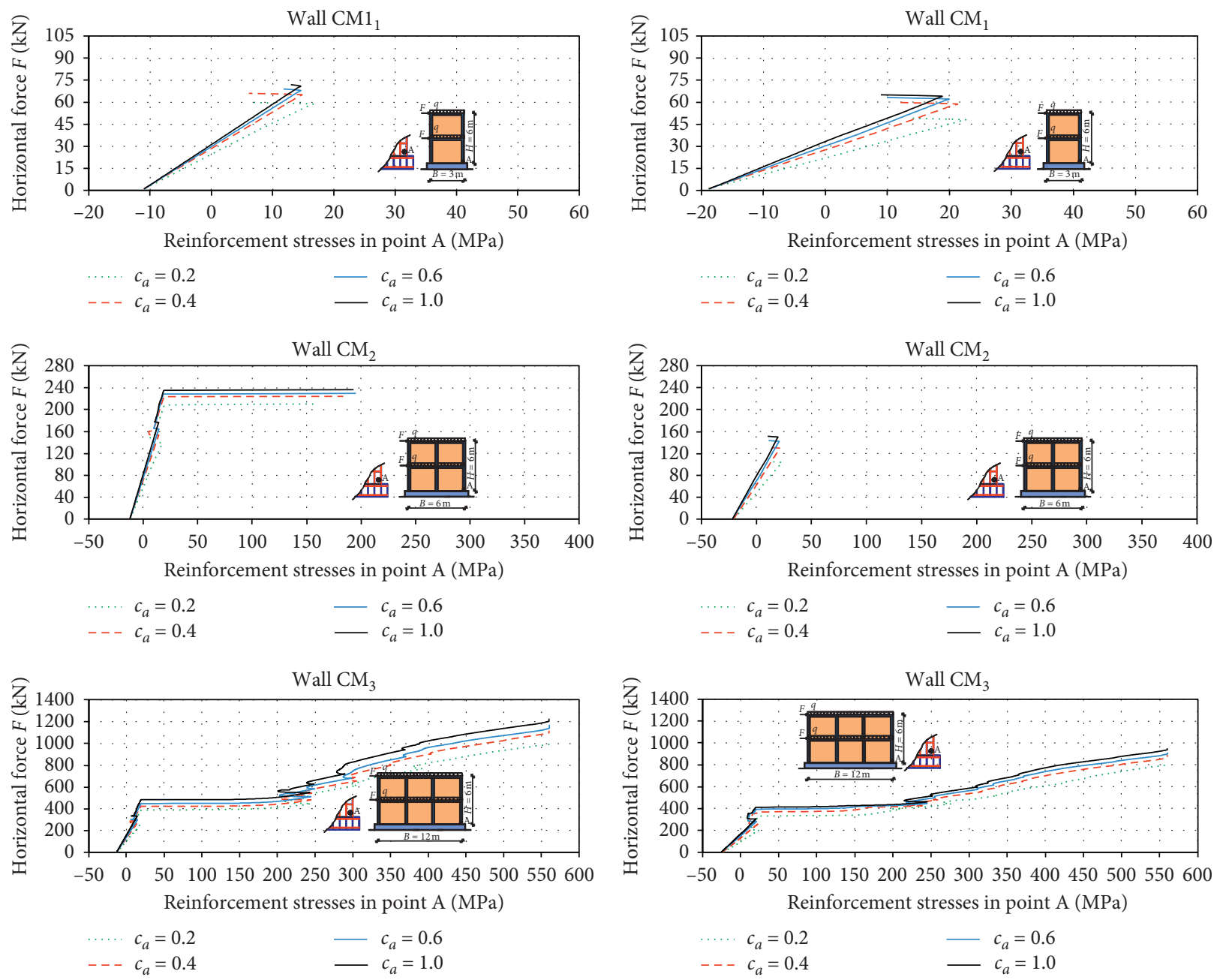

(a)

(b)

FIGURE 15: Reinforcement stresses in point A of confined masonry walls: (a) stiff masonry; (b) soft masonry.

As shown in the presented figures, limit strengths and displacements (deformability), as well as the stresses in masonry, concrete, and reinforcement, depend on the coefficient of anisotropy $c_{a}$. As the anisotropy of masonry is higher (smaller $c_{a}$ ), the difference in these values between walls with isotropic and anisotropic masonry is also higher. With the same coefficient of anisotropy, the behaviour of the masonry wall depends on the type of the walls (unreinforced and confined), on the height-length ratio of the wall, and on the quality of the masonry (stiff masonry and soft masonry).

Longer walls have a greater anisotropy effect relative to shorter walls. Soft masonry has a greater anisotropy effect relative to stiff masonry. The anisotropy effect is more affected by the horizontal displacement (deformability) of the wall and less affected by the ultimate bearing capacity. Confined masonry walls have a higher anisotropy effect relative to unreinforced masonry walls. For high values of the coefficient $c_{a}$ (lower anisotropy), the difference in behaviour between anisotropic walls and isotropic walls is small.

\section{Conclusions}

The presented numerical model for nonlinear analysis of planar masonry structures, which is upgrading of the previously developed model [26], can simulate their main nonlinear behaviour. The model is simple and primarily intended for practical application. Further verification of this numerical model is still required.

The ultimate bearing capacity, displacements, and stresses in considered confined and unreinforced masonry walls under horizontal static loads depend on the anisotropy of masonry, but not a lot. The reason is that the reduced masonry strength in the horizontal direction corresponds to significantly lower wall stresses in that direction, compared to vertical direction. As the anisotropy increases, the difference in the above wall values increases. The behaviour of masonry walls with low anisotropy is similar to the behaviour of walls with isotropic masonry. The anisotropy effect also depends on the type of the wall (unreinforced and confined), the quality of the masonry (stiff masonry and soft masonry), and the height-length ratio of the walls, but also 
not significantly. Confined masonry walls have a greater anisotropy effect than unreinforced masonry walls due to increased horizontal stresses in walls due to tie beams and tie columns. The anisotropy effect depends very little on the quality of the masonry. Longer walls have somewhat greater anisotropy effect than shorter walls. The aforementioned facts are the reason that, due to the tendency to reduce weight, masonry blocks with vertical cavities have long been used in practice. The use of soft masonry, especially those with a higher anisotropy, should be excluded in practice.

\section{Data Availability}

All data underlying the findings of the study are presented in this paper.

\section{Conflicts of Interest}

The authors declare that they have no conflicts of interest.

\section{References}

[1] A. Page, "The biaxial compressive strength of brick masonry," Proceedings of the Institution of Civil Engineers, vol. 71, no. 3, pp. 893-906, 1981.

[2] A. W. Page, "The strength of brick masonry under biaxial compression-tension," International Journal of Masonry Construction, vol. 3, pp. 26-31, 1983.

[3] A. W. Page, "Finite element model for masonry," Journal of the Structural Division-ASCE, vol. 104, no. 8, pp. 1267-1285, 1978.

[4] M. Dhanaeskar, P. W. Kleeman, and A. W. Page, "Biaxial stress-strain relations for brick masonry," Journal of the Structural Division-ASCE, vol. 111, no. 5, pp. 1085-1100, 1985.

[5] U. Andreaus, "Failure criteria for masonry panels under inplane loading," Journal of Structural Engineering, vol. 122, no. 1, pp. 37-46, 1996.

[6] P. B. Lourenço and J. G. Rots, "Multisurface interface model for analysis of masonry structures," Journal of Engineering Mechanics, vol. 123, no. 7, pp. 660-668, 1997.

[7] P. B. Lourénço, R. De Borst, and J. G. Rots, "A plane stress softening plasticity model for orthotropic materials," International Journal for Numerical Methods in Engineering, vol. 40, no. 21, pp. 4033-4057, 1997.

[8] P. B. Lourenço, J. G. Rots, and J. Blaauwendraad, "Continuum model for masonry: parameter estimation and validation," Journal of Structural Engineering, vol. 124, no. 6, pp. 642-652, 1998.

[9] C. Syrmakezis and P. Asteris, "Masonry failure criterion under biaxial stress state," Journal of Materials in Civil Engineering-ASCE, vol. 3, no. 58, pp. 58-64, 2001.

[10] L. Berto, A. Saetta, R. Scotta, and R. Vitaliani, "An orthotropic damage model for masonry structures," International Journal for Numerical Methods in Engineering, vol. 55, no. 2, pp. 27-157, 2002.

[11] C. Calderini and S. Lagomarsino, "Continuum model for inplane anisotropic inelastic behavior of masonry," Journal of Structural Engineering, vol. 134, no. 2, pp. 209-220, 2008.

[12] L. Pela, M. Cervera, and P. Roca, "Continuum damage model for orthotropic materials: application to masonry," Computer Methods in Applied Mechanics and Engineering, vol. 200, no. 9-12, pp. 917-930, 2011.
[13] L. Pelà, M. Cervera, and P. Roca, "An orthotropic damage model for the analysis of masonry structures," Construction and Building Materials, vol. 41, pp. 957-967, 2013.

[14] V. I. Lishak, V. I. Yagust, and D. Z. Yankelevsky, "2-D Orthotropic failure criteria for masonry," Engineering Structures, vol. 36, pp. 360-371, 2012.

[15] B. Ghiassi, M. Soltani, and A. A. Tasnimi, "A simplified model for analysis of unreinforced masonry shear walls under combined axial, shear and flexural loading," Engineering Structures, vol. 42, pp. 396-409, 2012.

[16] E. Grande, M. Imbimbo, A. Rasulo, and E. Sacco, "A frame element model for the nonlinear analysis of FRP-strengthened masonry panels subjected to in-plane loads," Advances in Materials Science and Engineering, vol. 2013, Article ID 754162, 12 pages, 2013.

[17] H. Basaran, A. Demir, and M. Bagci, "The behavior of masonry walls with reinforced plaster mortar," Advances in Materials Science and Engineering, vol. 2013, Article ID 436946, 9 pages, 2013.

[18] I. Caliò and B. Pantò, "A macro-element modelling approach of infilled frame structures," Computers \& Structures, vol. 143, pp. 91-107, 2014.

[19] R. Marques and P. B. Lourenço, "Unreinforced and confined masonry buildings in seismic regions: validation of macroelement models and cost analysis," Engineering Structures, vol. 64, pp. 52-67, 2014.

[20] P. G. Asteris, L. Cavaleri, F. Di Trapani, and V. Sarhosis, “A macro-modelling approach for the analysis of infilled frame structures considering the effects of openings and vertical loads," Structure and Infrastructure Engineering, vol. 12, no. 5, pp. 551-566, 2016.

[21] V. P. Berardi, "Initiation of failure for masonry subject to inplane loads through micromechanics," Modelling and Simulation in Engineering, vol. 2016, Article ID 2959038, 6 pages, 2016.

[22] M. Ridwan, I. Yoshitake, and A. Y. Nassif, "Proposal of design formulae for equivalent elasticity of masonry structures made with bricks of low modulus," Advances in Civil Engineering, vol. 2017, Article ID 6456070, 11 pages, 2017.

[23] B. Pantò, I. Caliò, and P. B. Lourenço, "A 3D discrete macroelement for modelling the out-of-plane behaviour of infilled frame structures," Engineering Structures, vol. 175, pp. 371385, 2018.

[24] X. Yang, H. Wu, J. Zhang, and H. Wang, "Shear behavior of hollow concrete block masonry with precast concrete antishear blocks," Advances in Materials Science and Engineering, vol. 2019, Article ID 9657617, 10 pages, 2019.

[25] K.-H. Yang, Y. Lee, and Y.-H. Hwang, "A stress-strain model for brick prism under uniaxial compression," Advances in Civil Engineering, vol. 2019, Article ID 7682575, 10 pages, 2019.

[26] J. Radnić, D. Matešan, A. Harapin et al., "Numerical model for static and dynamic analysis of masonry structures," in $\mathrm{Me}$ chanics and Properties of Composed Materials and Structures, Advanced Structured Materials, A. Öchsner, L. F. M. da Silva, and H. Altenbach, Eds., pp. 1-33, Springer-Verlag, Berlin, Germany, 2012.

[27] H. R. Ganz and B. Thurlimann, “Tests on masonry walls under normal and shear loading," Report No. 7502-4, ETH Zurich Institute of Structural Engineering, Zurich, Switzerland, 1984, in Geman.

[28] P. B. Lourenco, Computational strategies for masonry structures, Ph.D. thesis, Delft University of Technology, Delft, The Netherlands, 1996. 
[29] M. Smilović, J. Radnić, N. Grgić, and G. Baloević, "Effect of anisotropy of masonry on the behaviour of unreinforced and confined masonry walls under ground motion," in Engineering Design Applications. Advanced Structured Materials, A. Öchsner and H. Altenbach, Eds., vol. 92, pp. 173-186, Springer, Cham, Switzerland, 2018.

[30] J. Radnic, R. Markic, M. Glibic, N. Grgić, and I. Banović, "Comparison of numerical models for nonlinear static analysis of planar concrete frames based on 1D and 2D finite elements," Materialwissenschaft und Werkstofftechnik, vol. 47, no. 5-6, pp. 472-482, 2016. 